\title{
Politics and Procedure in Environmental Law
}

\author{
Daniel A. Farber \\ University of Minnesota
}

\section{Introduction}

Economists often take a jaundiced view of environmental legislation. They are generally skeptical of most current regulatory strategies and favor other mechanisms like marketable permits and emission fees (e.g., Portney). Yet, from the perspective of positive political theory, the puzzle is not that Congress produces public goods such as clean air so inefficiently, but that Congress manages to produce any public goods at all.

Despite their flaws, environmental statutes have produced genuine improvements in environmental quality. For instance, between 1970 and 1987, lead emissions declined 96 percent and sulfur dioxide emissions dropped 28 percent. Emissions of other air and water pollutants improved or remained relatively constant despite substantial economic growth. This record is especially impressive because GNP increased by 72 percent in the same period (and automobile use increased by about 50 percent) [Council on Environmental Quality (CEQ):8-9]. Although these improvements might have been obtained at lower cost, environmental statutes clearly have created important public benefits (Sunstein:76-9).

As Mancur Olson pointed out, the dynamics of collective action are actually quite adverse to the passage of statutes such as these, which involve the production of public goods. For example, almost everyone presumably bene-

Phil Frickey and Dan Gifford offered helpful comments on a previous draft, as did the discussants and other participants at the Allerton Conference.

(C) 1992 by Oxford University Press. All rights reserved. ISSN 8756-6222 
fits from improved air quality. An individual's support for pollution regulation, however, normally can have only an infinitesimal effect. Hence, a rational individual would usually "free ride" on the efforts of others, contributing nothing to environmental protection while benefiting from other people's actions. Because of this "free rider" problem, it should be relatively difficult to organize large groups of individuals to seek broadly dispersed public goods. Politics should instead be dominated by the rent-seeking activities of special-interest groups (Shaviro:40; Macey, 1988:474-80).

The thrust of this theory has been aptly summarized by Bill Eskridge:

\begin{abstract}
Although the interest group model of the legislative market is necessarily hedged with caveats and expressed in terms of probabilities, its general thrust is pretty grim. The legislative market is one that works badly. The public goods that government ought to be providing . . . are seldom passed by the legislature, because demand for them is usually not strong and legislators gain too little from sponsoring them. . . .

Conversely, rent-seeking statutes-primarily, concentrated benefit, distributed cost measures-seem inevitable.
\end{abstract}

This theory is not only theoretically plausible, but also has a fair amount of empirical support. For instance, the theory is corroborated by the prevalence of pork barrel legislation that produces local benefits but a net social loss.

The Olson paradigm appears to have a straightforward implication for environmental legislation: there should not be any. For example, air pollution legislation benefits millions of people by providing them with clean air; it also imposes heavy costs on concentrated groups of firms. The theory predicts that the firms will organize much more effectively than the individuals, and will thereby block the legislation. We would also expect to find little regulation of other forms of pollution. Similarly, we would also expect firms to block legislation limiting their access to public lands. Thus, the two basic predictions are that environmental groups will not organize effectively and that environmental statutes will not be passed (Elliot, Ackerman, and Millian:322).

Yet the reality is quite different. (Rubin:12). Environmental groups manage to organize quite effectively. As of 1985 , for example, the Sierra Club had 368,941 members, while the National Wildlife Federation had 853,000. Environmental groups also have substantial budgets (as high as $\$ 50$ million) and staff that run into the hundreds, including economists, lawyers, and other professionals (Ingram and Mann:140, 153). Nor, obviously, is there any dearth of federal environmental legislation. ${ }^{1}$

The gap between prediction and reality is so stark partly because the statement of interest-group theory given here (and common in the legal literature) is relatively unsophisticated. In its simplest guises, interest-group theory predicts that large groups should not be able to organize at all. More sophisticated forms of the theory qualify this prediction. Some members of the groups may have disproportionately large individual benefits from legislation. For

1. The West Publishing Company publishes a volume entitled Selected Environmental Statutes. The 1991-92 edition is 1,256 pages long. 
these group members, the marginal benefit from political organization may be positive (Stigler). This effect might be especially strong if some of the group members in question are altruistic, so they count the spillover benefits to other group members as benefits to themselves. (Ralph Nader may be the paradigm example.) As we will see, these qualifications help explain the formation of environmental groups, although the full explanation is more complex. Thus, the very existence of environmental groups is not necessarily a surprise.

The more fundamental problem, however, relates to political outcomes. The core prediction of interest-group theory (the dominance of "special interests") does not depend on the absolute weakness of broad, diffuse groups. Rather it depends on their relative weakness compared to smaller, more concentrated groups with equivalent total stakes. Even apart from the free-rider problem, smaller groups would be easier to organize simply because of lower transaction costs. Moreover, the free-rider problem itself is likely to be less severe for smaller groups, because group members begin with relatively larger individual shares of expected benefits. ${ }^{2}$ Thus, we would expect the more concentrated group to muster greater political resources in such forms as campaign contributions and professional lobbying. Indeed, this appears to be true: while the budgets of environmental groups are substantial, they certainly do not compare with the resources available to the major corporations, which typically suffer the costs of regulation. Yet, environmental legislation is enacted anyway. Thus, even the sophisticated form of interest-group theory seems to fail as a prediction of political outcomes.

In this article, I seek not to "debunk" interest-group theory, but to explain how the political system manages to overcome the inherent advantages of special interests. Synthesizing prior scholarship on the subject, I identify a symbiotic relationship between legislators and environmental groups. ${ }^{3}$ Briefly, the passage of environmental laws is attributable to strong public demand, coupled with exploitation of that demand by ideological and credit-seeking politicians. Environmental groups serve legislators by acting as information brokers during the enactment process, and by invoking procedural control mechanisms during the implementation phase. In return, environmental legislation promotes the growth of the environmental groups themselves.

This theory sheds light on recent changes in standing doctrine. In the past, litigation by environmental groups has been one important procedural control mechanism. Recently, the Supreme Court has given signs of being less sym-

2. To take an extreme case, suppose that $\$ 1$ of lobbying produces a total benefit to the group of $\$ 2$. A rational individual will lobby only if her own gain exceeds $\$ 1$. If there are only two group members, benefits need by only slightly asymmetrical in order to give one member of the group a sufficient motivation to lobby. On the other hand, if there are a thousand members of the group, a single member needs to have a benefit level over one thousand times the group average in order to be motivated to lobby.

3. Some of the primary elements of this synthesis are taken from an important study of the passage of the Clean Air Act [Elliot, Ackerman, and Millian (hereinafter referred to as EAM)] and the collaborative work of McCubbins, Noll, and Weingast $(1987 ; 1989)$ on administrative procedure (hereinafter referred to as McNollgast). 
pathetic to this function. Congress may respond by attempting to facilitate environmental litigation in various ways, or by shifting to other types of control mechanisms.

\section{The Sources of Environmental Legislation}

\subsection{Special Interests and Environmental Law}

The simplest explanation for the passage of environmental laws is that they actually reflect the influence of special interests rather than the preferences of the general public. The special interest involved may be variously depicted as either a producer interest or a consumer interest.

\subsubsection{Environmental Statutes as Industry Rent-Seeking. The producer theory} is that environmental statutes are actually blinds for rent-seeking by the regulated industries themselves. Thus, as Jon Macey puts it, "environmental protection statutes, which appear to be classic public interest statutes designed to ensure the optimal production of a public good (i.e., a clean environment), often contain features consistent only with the protection of special interests" (1988:508). Taking advantage of the public desire for environmental protection, firms procure statutes that are actually designed to profit the purportedly regulated industries (Pashigan, Bartel and Thomas).

Environmental statutes clearly do impose heavy costs on firms (Kahn:309). The special-interest story, then, involves differential costs between different segments of industry, which are thought to give the favored segments an advantage. There are two problems with this theory. ${ }^{4}$

First, the broad scope of environmental legislation is at odds with the theory. The number of firms involved seems too high to be plausible. Environmental legislation such as the Clean Air Act involves virtually every industry. 5 Even if only large firms benefit, passage of the legislation would still require organizing the efforts of many politicians and of firms in multiple industries (Kahn:308). Apart from the transaction costs involved in organizing a lobbying effort on this scale, such a widespread effort would create a high risk of public disclosure. There would be obvious rewards to any media firm that uncovered the industry conspiracy behind major pending legislation. ${ }^{6}$ Even if these organizational problems are not severe enough to make broad-scale

4. An additional problem is that the economic advantage to the "favored" firms is unclear. The best they can hope to do is to block entry by new firms and eliminate all "disfavored" firms from the market. At that point, they will have lowered industry output, which will force up the price. Thus, they will have the benefit of a noncompetitive price. But in the meantime, they themselves will have been forced to engage in high expenditures for pollution control equipment (see, e.g., Portney). Thus, even if the scheme works perfectly, we have the same somewhat dubious economics often connected with predatory pricing schemes: the short-term costs are so high that the long-term monopoly profits seem a doubtful incentive.

5. Some legislation does affect only a single industry, for example, restrictions on oil and gas production on public lands. But it is difficult to see how those restrictions can benefit oil companies, since prices are already set at monopoly levels by OPEC.

6. See Shaviro (96-100) and Levine and Forrence (188) on the role of the media in exposing interest-group activities. 
legislation impossible, it clearly would be easier for the key firms in particular industries to organize than to organize a single economy-wide effort. ${ }^{7}$ (Note that there may be conflicts between industries, since efforts to increase rents for suppliers will usually disadvantage firms that purchase their products.) Hence, if firms were providing the primary impetus for environmental legislation, we would expect to find that most environmental regulation originated in industry-specific legislation. This pattern was characteristic of earlier economic regulation, but has not been typical of environmental laws.

Second, the idea that environmental legislation is essentially a sham, used to conceal only special-interest benefits to producer groups, is itself incompatible with positive political theory. Positive theory assumes that voters are economically rational. Such voters should have "rational expectations." But if the Olson theory is correct, and if voters have rational expectations, they cannot be deceived by the appearance of "public-interest" legislation. Knowing the Olson theory, rational voters would realize that the legislation must instead be intended to benefit some special interest at their expense. Hence, there would be no point to the deception; no one would ever believe that the purported public-interest motivation of the legislation was real (Wittman:1409).

The same problem attends a variant of the producer theory involving administrative delegations. Neil Komesar argues that widespread expressions of environmental enthusiasm by politicians do not translate into effective regulation because industry captures the implementation phase (Komesar:49-50). This theory claims that producer groups cannot prevent the passage of legislation but can obtain a broad delegation of power to the agency, which they can thereafter capture (Rubin:22-3).

This theory does fit common ideas about legislative motivation, according to which members of Congress prefer broad delegations so they can "pass the buck" and avoid taking responsibility for the consequences of legislation (Eskridge:288-9; Aranson, Gelhorn, and Robinson:55-62). If there is a conflict between important political groups, the last thing a legislator wants to do is to take sides, thereby making political enemies. If one group is better able than the other to monitor administrative action, the legislator can have the best of both worlds. The group with higher monitoring costs-here, the publicis pleased by the passage of apparently constructive legislation, but cannot monitor the ultimate administrative outcomes. The more observant group (industry) is mollified by the knowledge that the administrative action will actually work to its advantage. So everyone goes away happy. ${ }^{8}$

Again, this theory depends on voter myopia. Voters who have rational

7. As noted earlier, while asymmetrical stakes may reduce free-rider problems, this becomes less likely as the number of firms increases.

8. It is not at all clear that broad delegations actually correlate with disparities in monitoring costs. The president has been delegated broad power regarding tariffs, for example. Yet, the industry groups who are likely to be hurt by actual presidential decisions are well-organized, while the consumers who benefit from the presidential commitment to free trade are not. The National Labor Relations Board has a very broad delegation, but both of the affected groups (industry and labor unions) have similar monitoring costs. 
expectations should know they have poorer monitoring abilities than industry. They should then predict that delegations will result in unfavorable administrative decisions. Hence, they should not be fooled by congressional delegations. Realistically, we cannot expect anything close to perfect rationality. But it is not implausible to expect that voters will realize that politicians may exploit their relative lack of information. Nor is it implausible to expect them to learn over time that they may be duped and to respond rationally to that knowledge. In short, the delegation and special-interest theories seem unsustainable as long-run equilibria.

This does not mean, of course, that industry groups play no role in shaping environmental legislation. To the extent that alternate regulatory methods can achieve similar environmental results, environmental groups may be relatively indifferent, so the final choice may be heavily influenced by industry lobbying. On occasion, environmental groups and industry also may form a coalition, to obtain legislation that for varying reasons is beneficial to both. Thus, domestic car producers may support safety standards that discriminate against foreign producers, or large textile or chemical firms may support environmental standards that discriminate against their smaller competitors. While the original "push" for this regulation may not have been to particularly hurt foreign or small competitors, that may have been the price that had to be paid to have the support of the affected industry. Moreover, industry opposition may often result in legislative compromises between economic and environmental goals. Industry may even promote environmental legislation on its own, as a way of heading off an environmental backlash. Thus, in various ways, industry may be an active participant in the passage of environmental legislations. Nevertheless, industry does not seem to provide the primary impetus for environmental legislation.

2.1.2 Rent-Seeking by Consumers. An alternative theory views environmental legislation as rent-seeking by "consumers" of environmental quality. In this view, environmental statutes are primarily designed to serve the interest of upper-middle-class backpackers, who have an unusually high demand for environmental amenities (Tucker:141-52).

One flaw in this theory is that some crucial environmental legislation passed before groups such as the Sierra Club had become politically formidable. For example, the National Environmental Protection Act and the Wilderness Act were passed in the 1960s, when the Sierra Club was a small California-based club of 35,000 members. Although it became an active litigant in the 1970s, not until 1980 did the Sierra Club engage in any political endorsements, and then on only a limited scale (Ingram and Mann:139, 147). Indeed, the Clean Air Act may have been strengthened as a result of the absence of any organized environmental lobby. Moreover, the financial resources available to environmental groups are much less than those of their industry opponents (Webb:10176).

More fundamentally, this theory underestimates the prevalence of environmentalist attitudes. In 1989,80 percent of the population agreed that 
"[p]rotecting the environment is so important that regulations and standards cannot be too high, and continuing environmental improvements must be made regardless of cost." 9 It is doubtful that voters would really support environmental regulation "regardless of cost," but their willingness to endorse this statement does show that they place a high value on the environment. Other studies of public opinion characterize environmentalism as a "consensual" value in American society (Dunlap). Indeed, environmentalist attitudes are now well-nigh omnipresent in American society, as Mark Sagoff shows in an important recent paper; he quotes Richard Darman (currently head of the Office of Management and Budget) as offering a particularly vivid description of this situation:

Increasingly, we are all environmentalists. The President is an environmentalist. Republicans and Democrats are environmentalist. Jane Fonda and the National Association of Manufacturers, Magic Johnson and Danny DeVito, Candice Bergen and "The Golden Girls," Bugs Bunny and the cast of "Cheers" are all environmentalist (Sagoff:1).

(See also Bush). In particular, Sagoff points out environmentalist attitudes are now found in publications that cater to groups quite different from the backpacker stereotype, including farm magazines, car and truck magazines, and hunting and fishing journals. Thus, environmental legislation seems to have a base of public support much broader than "wine and cheese" nature lovers.

In either its producer or consumer form, the special-interest theory falls short as an explanation of environmental legislation. This is not to say, of course, that particular features of specific environmental statutes never reflect the influence of producer groups or elite groups of nature lovers; it would be surprising to find that these groups had zero political influence. Thus, environmental legislation will tend to represent a balance between industry and environmental interests (Hahn:25-28). But taken as a whole, the existence of modern environmental legislation cannot be explained by the special-interest model. That model has a variety of weaknesses, and it is not surprising to find that it fails here. But its failure leaves a major puzzle. If environmental statutes do in significant part reflect a broad public demand, how does that demand get translated into legislation?

\subsection{Mass Politics and Political Entrepreneurs}

2.2.1 Public Opinion and Environmental Legislation. Classical public-choice theory tends to cut any link between public opinion and legislation, giving center stage to special-interest groups, with more widely dispersed preferences having only a peripheral role. Indeed, public-choice theory has some well-known difficulties accounting for the fact that people vote at all. Given the small chance of any individual vote influencing the outcome, voting seems irrational as an instrumental activity (see, e.g., Farber and Frickey:chap.1). In

9. New York Times, July 2, 1989, p. 1. See also New York Times, April 17, 1990, p. 1 ("The environment . . . has reached the forefront of American politics, with candidates for one political office after another proclaiming themselves environmentalist."). 
short, we would expect to see very little public attention to or influence on legislation (Shaviro:39-40, 58, 66).

An alternative tradition of political thought, that of civic republicanism, ${ }^{10}$ is represented in a recent article by James Pope:

Our history has from the outset been characterized by periodic outbursts of democratic participation and ideological politics. And if history is any indicator, the legal system's response to these "republican moments" may be far more important than its attitude toward interest group politics. The most important transformations in our political order . . . were brought on by republican moments (291-3).

As Pope defines these republican moments, their major features are (a) widespread public participation, taking the form of social movements and voluntary associations; and (b) utilizing a moral discourse appealing to concepts of the common good (p. 311). For present purposes, it is the first of these characteristics that is most significant. ${ }^{11}$

Putting aside the normative aspects of this theory, it adds a significant temporal dimension to the analysis. The implication is that politics alternates between normal periods, in which public attention to an issue is weak, and extraordinary periods, in which the issue has high salience for the public. In those extraordinary periods when broad segments of the public are intensely involved with an issue, legislators find themselves in the spotlight, and their positions shift closer to those of the public at large. During republican moments, voters acquire information about legislative positions, but they also acquire information about the state of the world that may lead to a change in their own expressed preferences. These periods are likely to be attended by new legislative initiatives responding to this public demand, which is less likely than legislation passed in other periods to be responsive to the demands of conventional interest groups.

The original 1970 Earth Day looks very much like a "republican moment." An estimated 20 million Americans participated in a variety of public events that day. More than 2,000 colleges, 10,000 high schools and elementary schools, and 2,000 communities took part. Some 20 years later, the reverberations were still being felt, as millions of people took part in a celebration of

10. Background on republicanism may be helpful for some readers. Philosophical liberalism has been the dominant strain in current American thought. In the 18th century, however, another political tradition was also highly influential, a tradition that stressed civic virtue-the willingness of individuals to sacrifice private interests to the public good. Modern reconstructions of republicanism are based on the allure of civic virtue. They view political life not merely as an effort to use the machinery of government to further the ends of private life, but as a distinct and in some respects superior sphere in which citizens rise above their merely private concerns to join in a public dialogue to define the common good (Sunstein:13-6, 35).

11. To some extent, the second characteristic probably flows from the first. Republican moments involve pressure for benefits that are broadly dispersed among large numbers of individuals. These public goods are likely to be discussed in terms involving appeals to group solidarity (because the benefit flows to the group as a whole), and mutual expressions of altruistic concern among the members of the group also help produce group solidarity. 
the 20th anniversary of Earth Day (Cahn and Cahn:16, 18-19, 37; CEQ:4-5). It is little wonder that environmental law has been used as a paradigm by republicans such as Sagoff.

The observation that environmental legislation has been driven by broad public opinion is not necessarily tied to republicanism or any normative political theory; it is ultimately an empirical assertion. Positive theory confirms that in periods of heightened public attention, legislative "shirking" will diminish, and legislative outcomes will be pushed in the direction preferred by the median voter (Levine and Forrence:192).

This view of the popular origins of environmental legislation is confirmed by an important historical study. In their investigation of the passage of the 1970 Clean Air Act, EAM found that organized environmental groups did not play a major role, nor did the activities of traditional industry interest groups. Instead, the primary motivating force was public pressure for environmental protection.

The term "republican moment" is perhaps misleading, to the extent that it suggests that very short periods of high-pitched public interest alternate with periods of nearly total public apathy. Rather, there is a continuum. Earth Day of 1970 represented a peak, but there have been lesser peaks of public pressure sparked by events such as Love Canal or Three Mile Island. In between these peaks, public attention is lower, but not nonexistent.

2.2.2 Legislative Motivation. Popular enthusiasm cannot by itself produce federal legislation; the Constitution provides no mechanism for direct democracy. If popular enthusiasm is to be translated into legislation, then legislators have to be actively involved. What is their motivation?

The EAM study suggests that one powerful motivation is the desire to earn a public reputation by taking credit for major reform legislation (see also Shaviro:83-4). This incentive is especially strong in the Senate, where a significant number of members have presidential aspirations. For example, one driving force behind the Clean Air Act was Senator Muskie's desire to establish himself as "Mr. Environment" (Dwyer:242-4; EAM:320-3). Once the legislative leadership defined the "environmentally sound" position, other legislators had a strong incentive to "get on board" or risk the wrath of an aroused public; the leadership proposal became the minimum measure of environmentally sound policy (Dwyer:244-5). ${ }^{12}$

12. In one survey, 15 percent of the public indicated that they probably would not vote for a congressional candidate whose views on pollution disagreed with their own. As critics of this survey pointed out, some other issues receive higher response levels on this question; for example, about twice as many respondents said they would not vote for a candidate with different views about abortion than their own. Issues such as abortion or affirmative action, however, are highly conflictual. Unless an environmental provision has a special economic impact in the district, the candidate has little to lose and much to gain by adopting the consensual public view. [Other studies have shown that only a few percent of voters report that environmental issues determined their vote, but this may be evidence that candidates have not taken sharply opposing views, rather than indicating the weakness of preferences (Dunlap:129-30).] 


\subsection{Symbolic versus Substantive Legislation}

2.3.1 "Lash Yourself to the Mast" and "Strike When the Iron Is Cold." The combination of republican moments and legislative credit-seeking provides a convincing explanation for the passage of environmental legislation. As the reference to republican "moments" itself suggests, however, waves of popular mobilization are usually intense but short (see Kahn:309-10). The rational strategy for legislators is, in the language of Roger Noll and James Krier, "to 'lash themselves to the mast' while waiting out the temporary siren calls for immediate overreaction"; the politicians then delegate to an agency on terms that will allow the "agency to 'strike when the iron is cold,' after the issue has lost its political salience" (774). Thus, as Noll and Krier say, we would expect to find a temporal instability, in which apparently bold legislative measures result in little actual implementation.

This phenomenon is certainly not unknown in environmental law. In an exhaustive study, John Dwyer demonstrates how this story played out with section 112 of the Clean Air Act, which purported to ban all toxic air pollution but was never actually implemented in its original form. By enacting the law, legislators gained the benefits of symbolic endorsement for "health and the environment" and against "trading lives for dollars"; while Congress's failure to decide the hard policy issues actually made the provision essentially a dead letter.

If the only operative forces were popular mood and legislative credit taking, symbolic legislation would be ubiquitous (Shaviro:8-9). Yet, as pointed out earlier, it is hard to see how this situation could be sustained in the long run unless voters are not just ignorant or even irrational but also outright fools, incapable of learning even after sustained experience.

Environmental legislation often does have a strongly symbolic nature and is rarely implemented to the full extent promised by the statutory language. Perhaps the most notorious example was the promise of the 1972 Clean Water Act to eliminate all pollution by $1985 .{ }^{13}$ Yet, this is hardly the full story. Even section 112, the provision discussed by Dwyer, was extensively amended as part of the 1990 Clean Air Act. It now contains highly burdensome and complex requirements for emitters of hazardous air pollutants. Rather than being a dead letter, the new statute promises to cost industry billions of dollars (Portney).

The history of section 112 suggests some of the empirical problems with the simple symbolic-legislation (or "lash yourself to the mast") model. First, the demand for environmental laws is less fitful than the model suggests. Most environmental statutes are not one-shot efforts, which are thereafter forgotten; they are likely to be followed by further legislation. For example, the Clean Air Act was passed in 1970 and extensively amended in 1977 and 1990; the Clean Water Act was passed in 1972 with substantial amendments in 1977 and 1987.

Second, in general, environmental laws seem to have greater long-term

13. 33 U.S.C. \$1251(a)(1). 
efficacy than this model suggests. They produce years of regulatory effort, often prompted by active litigation. Participants in the legislative process are quite aware that only implementation, rather than mere passage of a law, produces environmental improvements. ${ }^{14}$

Third, the programs contain far more substantive detail than can be easily accommodated by this model. While some of the legislation is symbolic, much of it seems to mean business. For instance, the 1990 amendments of the Clean Air Act demonstrate a serious commitment to implementation. Perhaps the most interesting provision is contained in the amendment to section 112. Cognizant of the possibility that Environmental Protection Agency (EPA) action may be hamstrung, the statute contains a burdensome default provision that promises highly stringent regulation unless EPA moves expeditiously. More generally, as McNollgast $(1987,1989)$ have explained, environmental statutes typically contain procedural mechanisms intended to preserve the original legislative deal. Usually, these mechanisms provide for hearing rights and judicial review at the behest of environmental groups, who can thereby keep the legislative effort from dissipating in the administrative process. In short, environmental law has much more durability and "bite" than seems plausible under the symbolic legislation model.

2.3.2 Incentives for Nonsymbolic Legislation. Why do legislatures enact real as opposed to symbolic legislation? Part of the motivation for environmental legislation may be ideological. For example, Earth Day was the brainchild of Senator Gaylord Nelson, who had previously demonstrated his environmental allegiance as governor of Wisconsin (Cahn and Cahn:18). Ideological legislators seek to screen legislation for substance as well as symbolism, since they care about policy outcomes.

This explanation assumes, of course, that legislators' ideology has some causal influence on their behavior. There is a wealth of empirical evidence supporting this proposition. There are also two strong theoretical explanations. Ideological behavior may represent "shirking" by legislators-that is, the use of their offices to serve their own goals rather than those of constituents or interest groups. There is at least some empirical support for this view of legislator ideology (Aranson:283-84; Farber and Frickey:chap.1). An alternative view is that ideology serves constituents by decreasing monitoring costs (Rubin:34). By voting for a legislator with a strong ideological commitment on issues of concern to them, constituents can be assured that the legislator will implement those interests. Hence, constituents need not invest so much in monitoring the actual performance of legislators (Dougan and Munger; Macey, 1990:25). ${ }^{15}$

14. As David Doniger, a senior Natural Resources Defense Council lawyer, said when the 1990 Clean Air Act amendments were passed, "By and large the air doesn't get clean by passing this law. It gets clean by the E.P.A. and the states carrying out the new law" (New York Times, Oct. 23,1990 , p. A12, cols. 4-5, national edition).

15. If a legislator's ideology is largely in line with constituent desires, an incentive may actually exist for the legislator sometimes to take stands unpopular with constituents. By taking 
Credit-seeking legislators also have good reason to seek effective legislation. Typically, they will not be able to establish their positions as leaders on particular issues overnight. Rather, only a series of legislative initiatives can convince the media of their leadership role. Because of this delay factor, however, information will become available on the implementation of the legislator's earlier proposals. If these earlier proposals were purely symbolic, the media will dismiss the legislator as a lightweight. To be an effective credit seeker, it is important to avoid the appearance of pure credit seeking-to show that one is not "all hat and no cattle" or "all sizzle and no steak." Yet it is difficult to develop an image as a substantive player without actually delivering some substance.

Political parties may also be a subsidiary source of regulatory durability. As Jon Macey argues, political parties provide a mechanism by which relatively diverse citizen interests are represented in the legislative process (1990:23). The parties (as ongoing enterprises) have incentives like those of individual legislators to demonstrate ideological commitments on highly topical issues and to engage in credit-seeking behavior. These incentives are especially strong on issues like the environment, which are salient but nonconfiictual among voters. Like individual legislators, parties also have some incentive to demonstrate that their commitment on particular issues is substantive rather than merely symbolic. Thus, party organizations may attempt to pressure individual legislators toward more substantive stands, although the extent of the pressure they can exert is unclear.

What we have established so far is that some key political actors have incentives to do more than pass symbolic legislation-rather, they wish to be recognized as supporting substantive, durable regulation. The remaining issue is the role of environmental groups in this scenario.

\section{The Role of Environmental Groups}

The impetus for environmental legislation seems to be popular pressure rather than lobbying by environmental groups. Nevertheless, these groups are prominent features in the political landscape. This raises two questions: What role do these groups play in environmental law? And what factors account for the formation and growth of these groups?

\subsection{Environmental Groups as Legislative Information Brokers}

As we have seen, ideologues, credit seekers, and political parties have incentives to establish images for themselves as substantive "players," not merely symbol-mongers. But if their performances are to be effective, they require knowledgeable audiences. ${ }^{16}$ Without a reliable body of critics, as the EAM

occasional unpopular stands, the legislator can demonstrate that he or she is a "person of principle"-who can thereby be counted on to follow through on the remainder of the legislator's ideological beliefs, which are of greater interest to constituents. In other words, the legislator can assure a higher long-run reputation with constituents by making occasional short-term political sacrifices in the name of ideology.

16. The general public is presumably in a poor position to distinguish symbol from substance; and while the media may attempt to do so, it is unlikely that individual reporters will be able to 
study shows, politicians find themselves in a perilous situation. For example, Muskie and Nixon both wanted to establish images for themselves as sensible environmentalists. The problem was that there were no widely recognized environmental groups to anoint them, so Muskie had no one with whom he could bargain and no way of knowing "how much would be enough." The result was that he proposed a version of the Clean Air Act similar to Nixon's but with more bite, leading to stronger legislation than a well-organized environmentalist lobby would have been able to obtain (EAM:338).

Politicians gain from the existence of groups that can provide voters with endorsements of a politician's environmentalist credentials. The alternative is to face what EAM call a Politicians' Dilemma, where politicians find themselves expending unnecessary political capital in their competition to claim credit for making public policy. In this respect, the environmental groups serve something of the same informational purpose as the Underwriter's Laboratory does, by placing a stamp of approval on the product (see Wittman:1400).

Environmental groups also play other incidental roles within the legislature. As recent studies of the legislative process emphasize, one role played by policy advocates is to generate an inventory of proposals (Hirshman:650-3; Shaviro:83-5). Legislators cannot readily generate new regulatory ideas and therefore depend on others for proposals. Sometimes the policy advocates are academics (Aranson:285); but environmental groups may also generate such proposals, or they may repackage ideas generated by academics. For instance, the concept of marketable permits had long been a staple in the economics literature, but it was apparently the Environmental Defense Fund that produced the particular emission allowance proposal embodied in the 1990 Clean Air Act. ${ }^{17}$

Because environmental legislation is so complex, it is often difficult for legislators to be sure of just what they are voting for or what its effects will be. ${ }^{18}$ Because of the environmental group's incentives as a "repeat player" to maintain its reputation for reliability, such information may be relatively unbiased despite the group's status as an advocate. The availability of this information source is especially valuable to legislators because it offers a check on their other major source of such information, the executive branch. Particularly for legislators who are hoping to build reputations for themselves as policy players, it is crucial not to be completely dependent on the president and his underlings for information. ${ }^{19}$ Environmental groups are one of the sources of this information.

draw such distinctions reliably. Moreover, to demonstrate substantive competence, politicians need an audience that cannot only attest to their good intentions but also to their expertise. Another alternative is provided by "think tanks" and academic experts.

17. Minneapolis Star-Tribune, Oct. 28, 1990, p. 17A.

18. Litigation provides an opportunity to develop such information through discovery (Sive:670).

19. Moreover, because of their long-term involvement in the process, environmental groups may assist in coalition building. Even a casual reading of the history of the 1990 amendments to the Clean Air Act, for instance, makes it clear that some very complex political bargaining was taking place. Again, lobbyists, including public-interest groups, can help legislators obtain the information they need to maneuver successfully. 
Notably, all of these roles involve the provision of information. As compared with the ability to generate large campaign funds or other financial rewards, mere control over information may seem relatively inconsequential. But recall that in the Olson model, the entire political process is ultimately driven by information costs. In particular, the reason that legislators are free to respond to special interests is that information costs lead to rational voter ignorance (Aranson:273). For this reason, information brokers such as publicinterest groups can exercise important influence in the legislative process.

\subsection{Environmental Groups in the Implementation Process}

Once legislation is passed, its effectiveness depends on the implementation process. Legislators face serious problems in obtaining vigorous implementation by administrative agencies. Agencies may be captured by interest groups; they may be subordinate to presidents who are hostile to the legislation; or they may have their own bureaucratic agendas. Oversight hearings give the legislature some leverage, but the ability of legislators to monitor the agency's performance is limited. Moreover, the agency may be unresponsive to the sanctions available to the oversight committee, and procedural obstacles may make corrective legislation impractical (McNollgast 1987:246-53).

One set of solutions to these problems is procedural. As explained by McNollgast, several procedural strategies are available to the legislature. First, procedural obstacles to agency action may create sufficient delay for legislative oversight to mobilize. As Jon Macey (1992) points out, the delay also provides time to assess the impact of agency policy proposals. Second, the beneficiaries of regulation can be given access to agency procedures. Among other benefits, this allows the beneficiaries to act as "fire alarms," alerting the legislature to agency misbehavior. It also broadens the information base available to Congress in assessing the agency's decisions (Spiller and Urbizatondo). Third, the beneficiaries may be allowed to litigate against adverse agency decisions (McNollgast, 1987:263).

Where the beneficiaries of a regulation form a conventional interest group, these functions are readily served. A conventional interest group is more than willing to serve as a fire alarm, to litigate against adverse agency decisions, and to delay those actions with procedural maneuvers. But these functions are not so readily served when the agency's action affects a broadly dispersed group. In particular, there is no guarantee that victims of environmental degradation will be sufficiently well organized to participate effectively in the McNollgast control process. Yet unless someone can initiate these procedural mechanisms, they will remain unused, thereby depriving legislators of their intended effect.

Once again, environmental groups play a crucial role. Since early in the emergence of modern environmental law, these groups have been the major sources of litigation on behalf of environmental quality. The major national groups, most notably the Sierra Club and Natural Resources Defense Council, have participated in scores of major suits against EPA and other government 
agencies such as the Interior Department. Even a cursory study of environmental law reveals their pivotal role in shaping judicial decisions (Sive:639). They have also made effective use of litigation and other procedural delays to stall adverse agency action. Congress allowed them to pursue private enforcement actions as a substitute for agency enforcement. Moreover, environmental statutes typically allow citizens to sue violators for injunctions and civil penalties, and to collect attorney's fees if they prevail (Farber and Findley:502). These citizen suit provisions deliberately encourage environmental litigants to supplement government enforcement activities. ${ }^{20}$

The power of these techniques is best illustrated by the history of the Interior Department under the direction of James Watt. The various techniques discussed by McNollgast operated in tandem, in response to Watt's efforts to revamp departmental policy radically. Frequently, litigation would both delay a project and publicize opposition to Watt's position, accompanied by loud protest from congressional leaders. Ultimately, even when the environmental suit was unsuccessful on the merits, Congress either blocked the action through the appropriations process (avoiding the possibility of a veto), or exerted enough oversight pressure to force Watt to back down. The result was dramatic. Despite Reagan's overwhelming popularity, Watt's own dedication, and the strong support of important groups such as the oil industry, Watt achieved little of permanent importance (Coggins and Nagel).

As we have seen, environmental groups serve important functions in the legislative and implementation processes. This leaves unanswered, however, one final question: How do these groups overcome free-rider problems and other barriers to effective organization and growth?

\subsection{Formation and Growth of Environmental Groups}

After a group is going, various mechanisms may allow it to maintain its position or even grow. New mass-mailing techniques have proved especially useful because they make it possible to contact numerous potential contributors, so that the organization can rely on small contributions from many individuals (Ingram and Mann:150, Wilson:83-4). A small contribution is an easily affordable expression of ideological support, whose expressive value is probably great enough to provide adequate motivation. ${ }^{21}$ Moreover, small contributions may be partly explained as purchases of goods and services, such as membership magazines with interesting articles and pictures. Small contributors apparently do not invest much in monitoring organizations; this seems to reflect a limited commitment to the organization (Shaviro:95). But the very fact that the necessary commitment is limited also helps obviate the free-rider problem.

20. For a good description of the role of citizen suits, see Friends of the Earth v. Carey, 535 F.2d 165, 172 (2d Cir. 1976).

21. Smith gives membership fees ranging from $\$ 7.50$ to $\$ 25$ for major environmental groups. Many members of these groups actually make voluntary donations in excess of the membership fee, bringing the average contribution levels for these organizations up by several dollars. 
Because these marketing techniques involve economies of scale, however, they can be most effectively utilized by established groups. Moreover, individuals are much more likely to contribute to well-known groups than to possibly "fly by night" organizations. The same information costs that make it rational for individuals to remain ignorant and inactive actually work in favor of the group once it is established.

Moreover, after a group is active, some of its activities may be self-financing. Litigation generates attorney's fees. ${ }^{22}$ It also generates publicity for a group, and if its litigation is successful, the group can claim a judicial imprimatur for its positions and its effectiveness (Sive:640, Rabin:253). Lobbying can also be self-financing, in the sense that the new regulatory scheme may create an enforcement role (and subsequent attorney's fees) for the group.

Thus, the start-up phase is crucial (Hansen:94). How did environmental groups get to the point where they were big enough to be self-sustaining? There seem to be three answers. First, some groups that are active in environmental issues, most notably the Sierra Club, but also the Audubon Society and others, offer recreation-related services that led to their early growth (EAM:323). Second, other groups, such as the NRDC and the Environmental Defense Fund, were funded by major foundations; that funding (combined with effective litigation strategies) established them as successful organizations (Ingram and Mann:137-8). Third, ideology clearly plays a critical role in the formation and growth of these groups. The initial formation of the group involves particularly large contributions, both of cash and effort, and is thus likely to involve individuals with exceptionally high levels of ideological commitment.

Both the initial founding and subsequent growth of public-interest groups often involve threats that the status quo will deteriorate. Studies of environmental membership consistently show that members respond most actively to perceived threats to current environmental entitlements (Ingram and Mann:138-40). Surveys indicate that while majorities favor strengthening environmental laws, "huge majorities oppose weakening current efforts" (emphasis in original) (Dunlap:117). This may partly reflect endowment effects, which cause individuals to weight possible losses more heavily than gains. ${ }^{23}$ It may also reflect informational availability and salience. Changes in the status quo are much more likely to be publicized than maintenance of existing conditions (Noll and Krier:764-9). As a result, membership solicitations by environmental groups often stress recent disasters and apocalyptic prospects (EAM:323).

22. Public-interest lawyers often work for reduced rates, but federal awards of attorney's fees are based on the usual market rates, so litigation is potentially a profit-making activity. See Blum v. Stenson, 465 U.S. 886, 892-96 (1984).

23. It may also reflect the impact of existing legislation on public preferences, which may be one purpose of "symbolic" legislation (Hahn:35). 
These effects worked greatly to the advantage of environmental groups during the Reagan years. For instance, the Sierra Club grew only slowly during the Carter administration but nearly doubled its membership between 1980 and 1983 (Ingram and Mann:139). Thus, perceived threats to the environmental status quo are powerful inducements. These threats do not have to take the form of proposals to change substantive policy, as they did in the Reagan administration. They may also take the form of newly perceived problems, often exemplified (sometimes misleadingly) by dramatic incidents such as Love Canal or Bhopal (Noll and Krier:770).

Notably, environmental legislation itself may create the conditions in which unchanged conditions are perceived as constituting a threat to the "status quo." For example, as noted earlier, section 112 of the Clean Air Act purported to guarantee the elimination of all airborne carcinogens. In that form, the statute was never effectively implemented. The framing of issues can be quite important, however (Noll and Krier:768). Nonenforcement of section 112 could be effectively portrayed not as a continuation of the prestatutory status quo, but as a retreat from the statutory mandate. Combined with new information about the prevalence of hazardous air pollutants, the symbolic status quo meant that new legislation could be sold as an effort to maintain prior regulatory goals, never implemented and now known to be more important than ever. In short, even symbolic legislation can affect the framing of issues, and hence the motivation to join organizations.

In summary, there is a symbiotic relationship between legislators and environmental groups. Environmental groups perform two important functions for legislators. First, they help solve the "Politician's Dilemma" by giving legislators a reliable gauge of how their efforts will be publicly received. Second, they provide the crucial impetus for implementing the McNollgast procedural mechanisms used to prevent agencies from defaulting on their statutory mandates. In particular, they make possible the use of judicial review to control agencies.

In return, however, the environmental groups themselves receive two important benefits. First, participation in the implementation process provides publicity and attorney's fees. Second, the passage of environmental legislation creates a new set of environmental entitlements. Efforts to repeal those entitlements-or even failure to implement them-are then perceived as threats to the status quo, which spark increased organizational involvement. Congress needs the environmental groups, but at the same time, the environmental groups need Congress.

\subsection{Environmental Groups as Litigators: The Prognosis}

As we have seen, one central role played by environmental groups is to prevent agency "shirking" from legislative directives. One of the most effective forums for this role has been the judiciary. Recently, however, the Supreme Court has shown decreasing acceptance of the role played by environmental groups. 
In prior cases such as Sierra Clubv.Morton ${ }^{24}$ and $S C R A P I^{25}$ the Court had taken a lenient view of standing in environmental cases. In 1990, however, the Supreme Court signaled a sharp change in direction. The first indication of a changed attitude was a reference, in an nonenvironmental opinion, to $S C R A P I$ as involving "[p]robably the most attenuated injury" ever to confer standing, with the additional comment that SCRAPI "surely went to the very outer limit of the law." 26 A second, more serious signal followed later the same year, in Lujan v. National Wildlife Federation. ${ }^{27}$

Lujan involved a Bureau of Land Management (BLM) review of executive orders withdrawing many public lands from resource development. Justice Scalia's opinion for the Court held that the plaintiff lacked standing for two reasons. First, the plaintiff had attempted to establish standing by filing affidavits attesting to use of the affected lands by some of its members. The affidavits were defective, the Court held, because they alleged that the members used federal lands "in the vicinity" of those affected by the order. Justice Scalia concluded that actual presence, not merely proximity, was required. Second, even if those affidavits had been adequate, they would have established only the plaintiff's right to litigate about the specific lands used by those individuals, not the right to challenge the entire BLM program. Unless a statute specifically permits broad regulations to be directly reviewed, the plaintiff can challenge only some "concrete action applying the regulation to the claimant's situation in a fashion that harms or threatens to harm him."28

The first of these holdings requires more careful pleading in environmental cases, and probably will increase the amount of time and energy devoted to disputing standing issues. The second holding, requiring piecemeal litigation, probably will have more serious consequences by preventing unified litigation

24. 405 U.S. 727 (1972). Sierra Club involved an effort by the Sierra Club to overturn Forest Service approval of a private resort. The Sierra Club did not allege that its members would be directly injured by the construction of the resort. Instead, it sued on the basis of its status as an organization with a special, long-standing interest in preservation of the environment. Although some lower courts had indicated a willingness to confer standing based on similar allegations, the Supreme Court refused to do so. It did, however, hold that the Sierra Club would have standing if any of its members used the area and would suffer an aesthetic injury from construction of the resort.

25. United States v. Students Challenging Regulatory Agency Procedures, 412 U.S. 669 (1973). SCRAP I involved a challenge to an Interstate Commerce Commission rate-making order, which allegedly increased an already excessive disparity between rates for scrap and recycled materials. The plaintiffs' theory was that increased discrimination against recycled goods would further diminish the use of recycling, thereby augmenting the amount of litter on a nationwide basis-including the parks where they lived. They also alleged that the decrease in recycling would cause an increase in mining and logging in the region. Despite the attenuated chain of causation and fairly minimal injury claimed by the plaintiffs, the Supreme Court held that they did have standing (Fletcher:258-9). A similarly liberal grant of standing can be found in Duke Power Co. v. Carolina Environmental Study Group, 438 U.S. 59 (1978).

26. Whitmore v. Arkansas, 110 S.Ct. 1717 (1990).

27. 110 S.Ct. 3177 (1990).

28. Id. at 3190 . The opinion then points out that a major exception exists if a rule "as a practical matter requires the plaintiff to adjust his conduct immediately." Note that this exception is available only to regulated parties rather than consumer or environmental interests. 
against broad government programs (Sheldon:10565-6). Taken together, the two holdings signal a new seriousness in applying standing rules, which had become virtually pro forma after $S C R A P I$ in environmental cases.

Justice Scalia conceded that "[t]he case-by-case approach that this requires is understandably frustrating to an organization such as respondent's, which has as its objective across-the-board protection of our Nation's wildlife and the streams and forests that support it." ${ }^{29}$ Notably, this statement does not reflect any acknowledgment that environmental organizations are not merely satisfying the personal values of their members but also play an important role in implementing the congressional mandate (Sunstein:217).

One of the Court's concerns was apparently that environmental groups would use litigation to revise rather than implement the legislative mandate. Justice Scalia characterized the Lujan suit as an effort at "wholesale" regulatory reform, which should not be sought in the courts but rather "in the offices of the Department or the halls of Congress, where programmatic improvements are normally made." 30 Justice Scalia is correct that groups may seek to use litigation to rewrite the original legislative deal. Because environmental statutes often reflect a compromise between environmental and economic interest groups, environmental groups may seek to use litigation to obtain what they failed to obtain from Congress. Restrictions on standing, however, will have only a haphazard connection with the legal validity of the plaintiff's attack on the agency's procedures. Stricter standing rules will decrease the number of legally unfounded claims, including some efforts to rewrite the legislative "deal." But standing restrictions are equally likely to preclude efforts to enforce the original deal. Thus, restricting standing does not inherently enhance the durability of the original legislative deal.

Quite the contrary is true in environmental law. More restrictive standing rules are likely to have a differential impact. Industry groups can readily demonstrate economic harm, a traditional basis for standing. Thus, restricted standing rules will not affect their efforts to use the courts to rewrite legislative deals. When the original deal is in their favor, they will also be able to use the courts to enforce the deal. Because they lack the traditional economic injuries, environmental groups are likely to be more substantially affected by standing restrictions. Hence, they will be less able to enforce favorable legislative deals or to use the courts to rewrite deals in their favor. The net result is that restrictions on standing will tend to tug implementation away from the legislative deal toward industry interests.

From the perspective of positive theory, Lujan is not a surprising decision. The courts that decided Sierra Club and SCRAP I were decidedly more moderate than the current Supreme Court. The federal judiciary in general, and the Supreme Court in particular, is now markedly more conservative than Congress. Judicial preferences regarding environmental policy are undoubtedly more favorable to industry than are legislative preferences. Standing re-

29. 110 S.Ct. at 3191 .

30. Id. at 3190 . 
strictions implement these judicial preferences in a particularly economical way, because they apply across a broad range of statutes. The result is to shift outcomes toward the judges' ideal point in a broad range of cases.

Congress can be expected to respond in several ways. First, subject to some possible constitutional limitations, ${ }^{31}$ Congress may attempt to broaden standing. This effort may not be successful, since the president can be expected to oppose expansions of judicial review in favor of environmental groups. At best, this is only a partial solution to Congress's agency problem, because even if environmental groups are given standing, the judiciary will remain a relatively unsympathetic forum. A second response, then, is to write statutes in ever greater detail, so that judges (and administrators) will find it more difficult to shirk. This involves a variety of transaction costs, so we can also expect to see a third response, which is to increase reliance on nonjudicial control mechanisms. One possibility is to provide environmental groups with greater procedural rights, within both the administrative and the judicial processes. Even if the ultimate decisions in both processes are biased against the environmental groups, affording them additional procedural rights increases their leverage by allowing them to delay adverse decisions and render them more costly. Congress may also increase its reliance on oversight hearings and other control mechanisms.

\section{Conclusion}

I began this article by considering interest-group theories as they apply to environmental laws. These theories suggest that legislation is more likely to advance special interests than broad public preferences. Because political participation (including the acquisition of relevant information) is costly, concentrated groups find it easier than diffuse ones do to overcome collectiveaction problems. Yet, in the environmental area, statutes conferring broad public benefits nevertheless are enacted, and groups seeking those benefits do effectively organize.

Essentially, the explanation is that politicians are not merely passive exploiters of existing opportunities; they are also entrepreneurs who actively remold their environment. Public pressure for environmental measures created both opportunities and risks for legislators. ${ }^{32}$ The initial result was a disequilibrium in which legislators responded to the new political pressures with bold but partly symbolic legislation. Ultimately, however, a new equilibrium has emerged that fosters a symbiotic relationship between legislators and environmental groups. Environmental groups function largely to help legislators overcome information and monitoring problems, both in the enactment and the implementation phases of environmental legislation. Environ-

31. Article III of the Constitution, which limits federal courts to deciding "cases and controversies," may provide a constitutional basis for standing rules beyond the reach of congressional modification (Fletcher).

32. Public attitudes toward environmental issues shifted sharply between 1965 and 1970 (Dunlap:95-7). A fuller analysis of the politics of environmental law would require an understanding of this shift. 
mental legislation also takes account of industry interests, but environmental groups ensure that environmental goals are implemented as well.

If Lujan is an indication, the Supreme Court may be becoming increasingly unsympathetic with the role played by environmental groups. The positions taken by environmental groups do not necessarily represent the legislative intent, nor that of the median voter. Nor, obviously, need they be accepted as normatively correct; they may well overweight environmental values over other concerns. Nevertheless, their participation in the litigation process and in agency procedures has been a crucial part of the process by which environmental laws are made and implemented. Without the active participation of these groups, industry pressures on agencies might go uncountered. In the long run, Congress can overturn adverse judicial opinions in order to maintain its symbiotic relationship with environmental groups. But there are obvious lags and transaction costs in attempting to overcome judicial resistance. For this reason, Congress may shift toward other methods of preventing agency shirking. The courts may then play a decreasing role in environmental law.

\section{References}

Aranson, Peter. 1990. "Theories of Economic Regulation: From Clarity to Confusion," 6 Journal of Law \& Politics 247-86.

, Ernest Gelhom, and Glen Robinson. 1982. "A Theory of Legislative Delegation," 68 Cornell Law Review 1-67.

Bartel, Ann, and Lacy Thomas. 1985. "Direct and Indirect Effects of Regulation: A New Look at OSHA's Impact," 28 Journal of Law and Economics 1-25.

Bush, George. 1988. "George Bush on the Environment," 18 Environmental Law Reporter 10293-5.

Cahn, Robert, and Patricia Cahn. 1990. "Did Earth Day Change The World?" 32 Environment 16-43 (Sept. 1990).

Coggins, George, and Doris Nagel. 1990. “'Nothing Beside Remains': The Legal Legacy of James G. Watt's Tenure as Secretary of the Interior on Federal Land Law and Policy," 17 Environmental Affairs 473-537.

Council on Environmental Quality. 1990. Twentieth Annual Report. Washington, D.C.: U.S. Government Printing Office.

Dougan, William, and Michael Munger. 1989. "The Rationality of Ideology," 32 Journal of Law and Economics 119-42.

Dunlap, Riley. 1989. "Public Opinion and Environmental Policy," in James Lester, ed., Environmental Politics and Policy: Theories and Evidence. Durham, N.C.: Duke University Press.

Dwyer, John. 1990. "The Pathology of Symbolic Legislation," 17 Ecology Law Quarterly 233316.

Elliot, E. Donald, Bruce H. Ackerman, and John C. Millian. 1985. "Toward a Theory of Statutory Evolution: The Federalization of Environmental Law," 1 Journal of Law, Economics, \& Organization 313-40.

Eskridge, William, Jr. 1988. "Politics Without Romance: Implications of Public Choice Theory for Statutory Interpretation," 74 Virginia Law Review 275-338.

Farber, Daniel, and Philip Frickey. 1991. Law and Public Choice: A Critical Introduction. Chicago: University of Chicago Press.

- and Roger Findley. 1991. Environmental Law: Cases and Materials, 3rd ed. St. Paul: West Publishing.

Fletcher, William. 1988. "The Structure of Standing," 98 Yale Law Journal 221-91. 
Hahn, Robert. 1990. "The Political Economy of Environmental Regulation: Towards a Unifying Framework," 65 Public Choice 21-47.

Hansen, John. 1985. "The Political Economy of Group Membership," 79 American Political Science Review 79-96.

Hirschman, Linda. 1988. "Postmodern Jurisprudence and the Problem of Administrative Discretion," 82 Northwestern University Law Review 646-704.

Ingram, Helen, and Dean Mann. 1989. "Interest Groups and Environmental Policy," in James Lester, ed., Environmental Politics and Policy: Theories and Evidence. Durham, N.C.: Duke University Press.

Kahn, Peter. 1990. "The Politics of Unregulation: Public Choice and Limits on Government," 75 Cornell Law Review 280-312.

Kelman, Mark. 1988. "On Democracy-Bashing: A Skeptical Look at the Theoretical and 'Empirical' Practice of the Public Choice Movement," 74 Virginia Law Review 199-273.

Komesar, Neil. 1990. "Injuries and Institutions: Tort Reform, Tort Theory, and Beyond," $65 \mathrm{New}$ York University Law Review 23-77.

Levine, Michael E., and Jennifer L. Forrence. 1990. "Regulatory Capture, Public Interest, and the Public Agenda: Toward a Synthesis," 6 (Sp) Journal of Law, Economics, \& Organization 167-98.

Macey, Jonathan R. 1988. "Transaction Costs and the Normative Elements of the Public Choice Model: An Application to Constitutional Theory," 74 Virginia Law Review 471-518.

- 1990. "The Role of the Democratic and Republican Parties as Organizers of Shadow Interest Groups," 89 Michigan Law Review 1-29.

- 1992. "Organizational Design and Political Control of Administrative Agencies," 8 Journal of Law, Economics, \& Organization 93-110.

McCubbins, Mathew D., Roger G. Noll, and Barry R. Weingast. 1987. "Administrative Procedures as Instruments of Political Control," 3 Journal of Law, Economics, \& Organization 243-77.

- 1989. "Structure and Process, Politics and Policy: Administrative Arrangements and the Political Control of Agencies," 75 Virginia Law Review 431-82.

Noll, Roger and James Krier. 1990. "Some Implications of Cognitive Psychology for Risk Regulation," 19 Journal of Legal Studies 747-79.

Olson, Mancur. 1965. The Logic of Collective Action: Public Goods and the Theory of Groups. Cambridge, Mass.: Harvard University Press.

Pashigan, B. Peter. 1984. "The Effect of Environmental Regulation on Optimal Plant Size and Factor Shares," 27 Journal of Law and Economics 1-27.

Pope, James. 1990. "Republican Moments: The Role of Direct Popular Power in the American Constitutional Order," 139 University of Pennsylvania Law Review 287-368.

Portney, Paul. 1990. "Policy Watch: Economics and the Clean Air Act," 4 Journal of Economic Perspectives 173-81.

Rabin, Robert. 1976. "Lawyers for Social Change: Perspectives on Public Interest Law," 28 Stanford Law Review 207-61.

Rubin, Edward. 1991. "Beyond Public Choice: Comprehensive Rationality in the Writing and Reading of Statutes," 66 New York University Law Review 1-64.

Sagoff, Mark. 1990. "Three Essays on Ethics and the Environment," Selected Environmental Statutes. St. Paul, Minn.: West Publishing.

Shaviro, Daniel. 1990. "Beyond Public Choice and Public Interest: A Study of the Legislative Process as Illustrated by Tax Legislation in the 1980s," 139 University of Pennsylvania Law Review 1-123.

Sheldon, Karin. 1990. "NWF v. Lujan: Justice Scalia Restricts Environmental Standing to Constrain the Courts," 20 Environmental Law Reporter 10557-66.

Sive, David. 1977. "Foreword: Roles and Rules in Environmental Decisionmaking," 62 lowa Law Review 637-42.

Smith, V. Kerry. 1985. "A Theoretical Analysis of the "Green Lobby," 79 American Political Science Review 133-47. 
Spiller, Pablo, and Santiago Urbiztondo. 1991. "Interest Groups and the Control of Bureaucracy: An Agency Perspective on the Administrative Procedure Act," unpublished manuscript on file with author.

Stigler, George. 1974. "Free Riders and Collective Action: An Appendix to Theories of Economic Regulation," 5 Bell Journal of Economics and Management Science 359-65.

Sunstein, Cass. 1990. After the Rights Revolution: Reconceiving the Regulatory State. Cambridge, Mass.: Harvard University Press.

Tucker, William. 1980. "Environmentalism: The Newest Toryism," Policy Review 141-52 (Fall 1980).

Webb, Ali. 1991. "A Green Party? Or Is the Party for Environmental Action Over?" 21 Environmental Law Reporter 10175-80.

Wilson, James Q. 1989. Bureaucracy: What Government Agencies Do and Why They Do It. New York: Basic Books.

Wittman, Donald. 1989. "Why Democracies Produce Efficient Results," 97 Journal of Political Economy 1395-427. 